\title{
Spatial Distribution of Armillaria mellea in Pear Orchards
}

\author{
D. M. Rizzo and E. C. Whiting, Department of Plant Pathology, One Shields Ave., University of California, Davis \\ 95616; and R. B. Elkins, University of California Cooperative Extension, 883 Lakeport Blvd., Lakeport 95453
}

\begin{abstract}
Rizzo, D. M., Whiting, E. C., and Elkins, R. B. 1998. Spatial distribution of Armillaria mellea in pear orchards. Plant Dis. 82:1226-1231.

Pears have traditionally been considered to be highly resistant to Armillaria root disease (causal agent: Armillaria mellea). In recent years, however, the incidence of Armillaria root disease in pears has increased in California. To determine the spatial distribution of Armillaria root disease in the field, a total of 156 isolates of Armillaria were collected from dead and dying pear trees located within two orchards in Lake County. All isolates from these two orchards, as well as from an additional 10 pear orchards, were identified as Armillaria mellea sensu stricto. Based on pairings among 102 Armillaria isolates, four somatic incompatibility groups (SIGs) were identified at orchard 1 . Three of the four SIGs at this site were over $100 \mathrm{~m}$ in length; the largest SIG was at least $200 \mathrm{~m}$ in length. Pairings among 54 isolates identified five SIGs at orchard 2. The SIGs at orchard 2 were generally smaller than those detected at orchard 1 and ranged from 20 to $60 \mathrm{~m}$ in length. The size of the SIGs points toward long-term establishment of the fungus on the two sites, most likely predating the establishment of the pear orchards. Extensive root excavations of 19 trees indicated that the primary means of secondary spread of Armillaria was via rhizomorphs, as opposed to root-to-root contact.
\end{abstract}

Armillaria root disease is an important disease of fruit, nut, and vine crops in California. Of all the deciduous fruit crops in California, pears have been considered among the least susceptible to infection by Armillaria (14,17,24). French pear, Bartlett rooted cuttings, Old Home $\times$ Farmingdale (all Pyrus communis), P. betulaefolia, and $P$. calleryana have all been listed as "immune or highly resistant" (18). Based on this premise, pear has been recommended as an alternative crop to replant sites in which Armillaria has been demonstrated to be a potential problem (23). Beginning around 1990, however, reports of Armillaria-infected pear trees increased in the North Coast mountain district of Lake County. In this area of California, 2,440 ha of European pears (mainly Bartlett, but also Bosc and red varieties) have been grown for over 100 years on valley soils cleared of oak (Quercus spp.) and other native hardwoods. Reports of increased incidence of Armillaria root disease in pear have also come from Sacramento, Mendocino, and El Dorado counties in northern California.

Few studies have been conducted on Armillaria distribution, spread, virulence, and inoculum survival in California orchard crops. In California, research on

Corresponding author: David M. Rizzo

E-mail: dmrizzo@ucdavis.edu

Accepted for publication 28 July 1998.

Publication no. D-1998-0831-01R

(C) 1998 The American Phytopathological Society
Armillaria root disease has concentrated primarily on soil fumigants and, to a lesser extent, biological controls $(11-13,15)$. The pending loss of methyl bromide as a fumigant will necessitate the development and testing of alternative control measures. This will require an understanding of the life history of the pathogen and the interaction between cultural practices and subsequent disease expression. The studies reported here are the first of several to determine the underlying reasons for the increased incidence of Armillaria root disease in pears. Our objectives in this study were to (i) examine the population structure of the fungus as a means to determine the epidemiology of the disease, and (ii) examine in detail the root systems of infected pear trees to understand the spread of the pathogen in pear orchards.

\section{MATERIALS AND METHODS}

Study sites. Two pear orchards in Lake County, California, were chosen for detailed study. These sites were selected because numerous disease foci were found within the confines of a single orchard.

Orchard 1 was a Bartlett pear orchard currently planted on a $4 \times 4 \mathrm{~m}$ spacing. The orchard was initially established in the late 1800s on French domestic rootstock. Some of these original trees are still found in the orchard, but numerous interplantings have been made with various rootstocks $(P$. betulaefolia, Winter Nelis, and $\mathrm{OH} \times \mathrm{F}$ 97). Orchard 1 (Fig. 1) was located adjacent to a stream, and the soil was generally a clay loam with gravel streaks running through it. The orchard was flood irrigated until 1971, when solid set sprinklers were installed. Mortality due to Armillaria root disease was first noted by the grower in the late 1970s. Approximately 6 ha were surveyed for the presence of the disease in 1995 and 1996.

Orchard 2 was also a Bartlett pear orchard and was located approximately 15 $\mathrm{km}$ from orchard 1 . The orchard was originally planted in 1878 on a $10 \times 8 \mathrm{~m}$ spacing on French domestic rootstock. Many of the original trees are still found in the orchard. The orchard was interplanted in 1962 on various rootstocks (P. betulaefolia, Winter Nelis, Old Home), resulting in the current $4 \times 8 \mathrm{~m}$ spacing. The soil is a mixture of sandy loam and clay loam, and unlike site 1 , it is not located near an existing streambed. The orchard was flood irrigated until 1975, when solid set sprinklers were installed. Crown symptoms and mortality were first noted in the mid1980 s by the grower, although it was not recognized as Armillaria root disease at the time. Approximately 4 ha were surveyed for the presence of Armillaria in spring and fall 1997.

Isolations and species identification. All pear trees with typical root disease symptoms (i.e., poor shoot growth, premature yellowing and dropping of leaves, and dieback) were examined and sampled in each of the two orchards. Root systems were typically excavated by hand to $0.5 \mathrm{~m}$ from the base of the tree, and the bark was removed to look for mycelial fans and decay. Root surfaces, decayed wood, and the surrounding soil were also examined for the presence of rhizomorphs.

Isolations were made on water agar (WA, $15 \mathrm{~g}$ of Sigma agar per liter) amended with benomyl 50WP (4 $\mu \mathrm{g}$ a.i./ml) and streptomycin sulfate (100 $\mu \mathrm{g} / \mathrm{ml}$ ) added after autoclaving. Tissues were axenically removed in the laboratory from portions of mycelial fans and decayed wood that were previously not exposed. Rhizomorphs were rinsed under running tap water for $5 \mathrm{~min}$ and cut into 1-cm-long pieces; the rhizomorph pieces were then surface-disinfected with $70 \%$ ethanol for 1 to $2 \mathrm{~min}$ and rinsed in sterile distilled water prior to plating on WA. Isolation plates were incubated at room temperature (20 to $22^{\circ} \mathrm{C}$ ) and examined after 5 to 10 days. Subcultures of Armillaria were transferred to $1 \%$ malt extract agar. Long-term storage of isolates was at $4^{\circ} \mathrm{C}$ under sterile distilled water in glass screw-top tubes.

Representative isolates from the two study orchards were identified to Armillaria species by utilizing the polymerase 
chain reaction (PCR) method of Harrington and Wingfield (4). Armillaria isolates were also obtained from 10 additional commercial pear orchards in Lake, Sacramento, and Mendocino counties. Isolates were grown on $1 \%$ malt extract agar overlaid with cellophane. To obtain template DNA for the PCR, a pipette tip was gently scraped across the mycelial mat on the cellophane (4). The intergenic spacer region (IGS) of the nuclear ribosomal DNA repeat was amplified using primers O-1 and LR12R (4). Thermocycler (Stratagene, Inc., La Jolla, CA) conditions were 35 cycles of $60^{\circ} \mathrm{C}$ for $1 \mathrm{~min}, 72^{\circ} \mathrm{C}$ for $1 \mathrm{~min}$, and $94^{\circ} \mathrm{C}$ for $30 \mathrm{~s}$. A final elongation was set at $72^{\circ} \mathrm{C}$ for $10 \mathrm{~min}$. The PCR products were digested with the restriction enzyme $A l u \mathrm{I}$ and run out on an agarose gel to look for restriction fragment length polymorphisms (RFLPs).

Somatic incompatibility pairings. All Armillaria isolates from sites 1 and 2 were assigned to somatic incompatibility groups by pairing the diploid isolates on ShawRoth media (40 g of Difco malt extract, 20 $\mathrm{g}$ of dextrose, $5 \mathrm{~g}$ of Difco Bacto-peptone, and $15 \mathrm{~g}$ of agar per liter) (21). Mycelial plugs of diploid isolates were placed 5 to $10 \mathrm{~mm}$ apart and incubated at room temperature for 4 to 6 weeks. To reduce the total number of pairings, four or five isolates were chosen from scattered locations at each of the two sites and used as testers. The testers were paired with all other isolates from that orchard. Isolates that were not compatible with the testers were paired among themselves in all possible combinations. Tester isolates were also paired among themselves, including self pairings as controls. Representatives of putative somatic incompatibility groups (SIGs) from each orchard were paired in all possible combinations. Paired isolates that grew together to form a homogenous colony with no dark lines or other barrage zones were considered to be of the same SIG $(5,19,20)$. Ambiguous pairings were retested, and all isolates eventually were assigned to a SIG.

Root system excavations. At orchards 1 and 2 , nine and 10 trees, respectively, were chosen for extensive root excavation to determine the spatial distribution of $\mathrm{Ar}$ millaria on the root systems of individual pear trees. At both sites, trees were selected to represent a range of crown conditions (from declining to apparently healthy) in and around an Armillaria infection center. Prior to excavation, tree crowns were visually rated on a scale of 1 to 5 (1, healthy, full crown with good shoot growth; 2, reduced top shoot growth; 3 , most shoots with reduced growth; 4, dieback evident, leaves small and lighter in color; 5, dead).

Root systems were excavated utilizing one of two methods. At orchard 1, pressurized water was used to remove soil from the roots of the selected trees. Prior to excavation, the soil surrounding the trees had been irrigated to saturation. During excavation, water was delivered to the roots with a hand-held automatic pressure controlling fire-fighting nozzle (TFT brand, Mid-Matic model), supplied by a $4.45-\mathrm{cm}-$ diameter fire hose at $5.3 \mathrm{~kg} / \mathrm{cm}^{2}$ (75 psi). The soil-water slurry was removed by a Vactor brand mobile industrial-vacuum conveyor through a $1.2-\mathrm{m}$-long rigid plastic tip on 20-cm-diameter flexible tubing.

Supersonic air was used to excavate root systems at orchard 2. The air was delivered through an engineered air jet nozzle and a $3.2-\mathrm{cm}$-diameter hose at $93.5 \mathrm{hl} / \mathrm{min}$ (330 cubic feet $/ \mathrm{min}$ ) at $7 \mathrm{~kg} / \mathrm{cm}^{2}$ (100 psi). The soil was rapidly pulverized and relocated in this process. The air penetrated the soil, filling soil pores until the soil suddenly failed in tension and exploded away in the direction of least resistance. This procedure utilizes the soil pores for air penetration, which causes localized soil structural failure. Soil moisture was maintained at field capacity for excavation; this allowed for soil pores to be maintained while lubricating soil particles for enhanced rate of excavation. Soil was removed during excavation as described above. Following soil removal, a thin film of clay particles remained on the root surfaces; this was washed off with water from a hand-held spray tank.

Root systems were excavated to a minimum diameter of $2 \mathrm{~m}$ from the stem and a minimum depth of $1 \mathrm{~m}$. The area between adjacent trees was also excavated to examine root overlap. Root systems were examined periodically during the excavation process to ascertain that critical information was not lost. Soil pits were examined for the presence of inoculum. Both methods resulted in the loss of the smallest fine roots; however, small roots $(1 \mathrm{~mm}$ diameter) were left intact. Epiphytic rhizomorphs were generally not affected by the excavation techniques. Following soil removal, root systems were individually dissected using hand tools and photographed. The exposed roots were examined for signs of Armillaria. The presence of various host responses (e.g., callus formation, cracking of bark), as well as extensively decayed roots, allowed for the location of Armillaria infections. Fungal samples were removed from lesions, decayed portions of the root system, and rhizomorphs; isolations were made in the laboratory as described above.

\section{RESULTS}

Isolation and identification of Armillaria. A total of 156 Armillaria isolates were collected from dead and dying pear trees at the two orchards. A single isolate

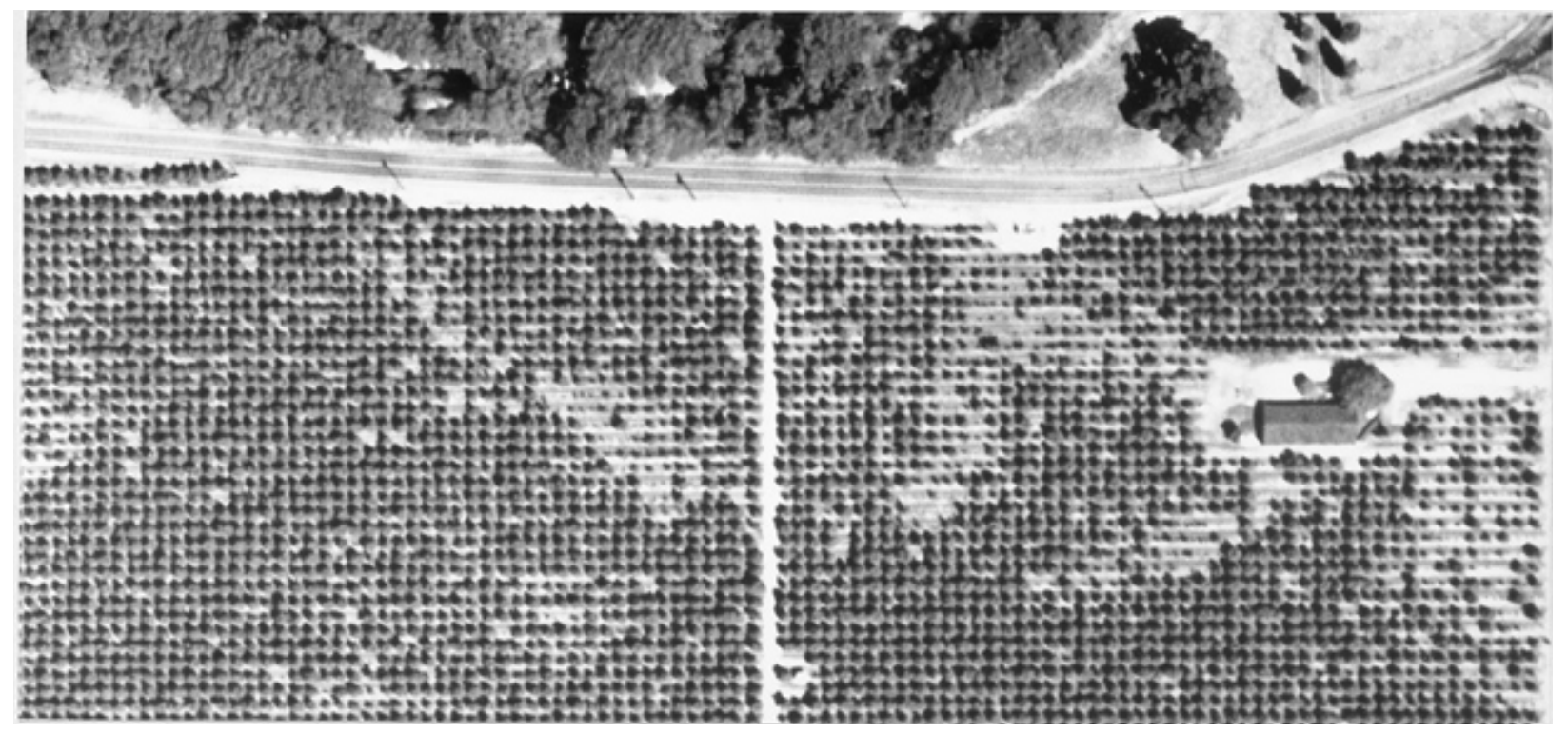

Fig. 1. Aerial photograph of orchard 1. Open areas in the orchard were caused by Armillaria root disease. Trees at the top of the photograph are part of a riparian area. 
from each SIG (see below) was identified to species. All isolates were identified as Armillaria mellea (Vahl:Fr.) P. Kumm. With each of these nine isolates, an 890-bp product was obtained following PCR, and AluI restriction resulted in fragments of 320 and $155 \mathrm{bp}$, which corresponded to the A. mellea (B) pattern reported by Harrington and Wingfield (4). Fourteen Armillaria isolates from an additional 10 pear orchards were also identified as A. mellea sensu stricto based on the $A l u \mathrm{I}$ restriction pattern.

Spatial distribution of Armillaria SIGs. Based on pairings among $102 \mathrm{Ar}$ millaria isolates, four SIGs were identified at orchard 1 (Fig. 2). Three of the four SIGs at this site were over $100 \mathrm{~m}$ in length; the largest SIG was at least $200 \mathrm{~m}$. Because sampling was restricted to this specific orchard, the exact size of each of the SIGs is not known. For example, the smallest SIG, which consisted of only three isolates, was found along the edge of the orchard and may have extended into the riparian area across the road (Fig. 1). No intermingling was observed among the four different SIGs in the orchard (Fig. 2).

Active disease centers consisting of multiple dead and dying trees in single foci were found interspersed with areas of asymptomatic pear trees within the total area delineated by the larger three SIGs (Fig. 2). Armillaria samples were generally taken at the advancing margin of these disease centers (Fig. 2, arrows). In addition to these large, discrete disease centers, a number of samples were taken from single infected trees not associated with a disease

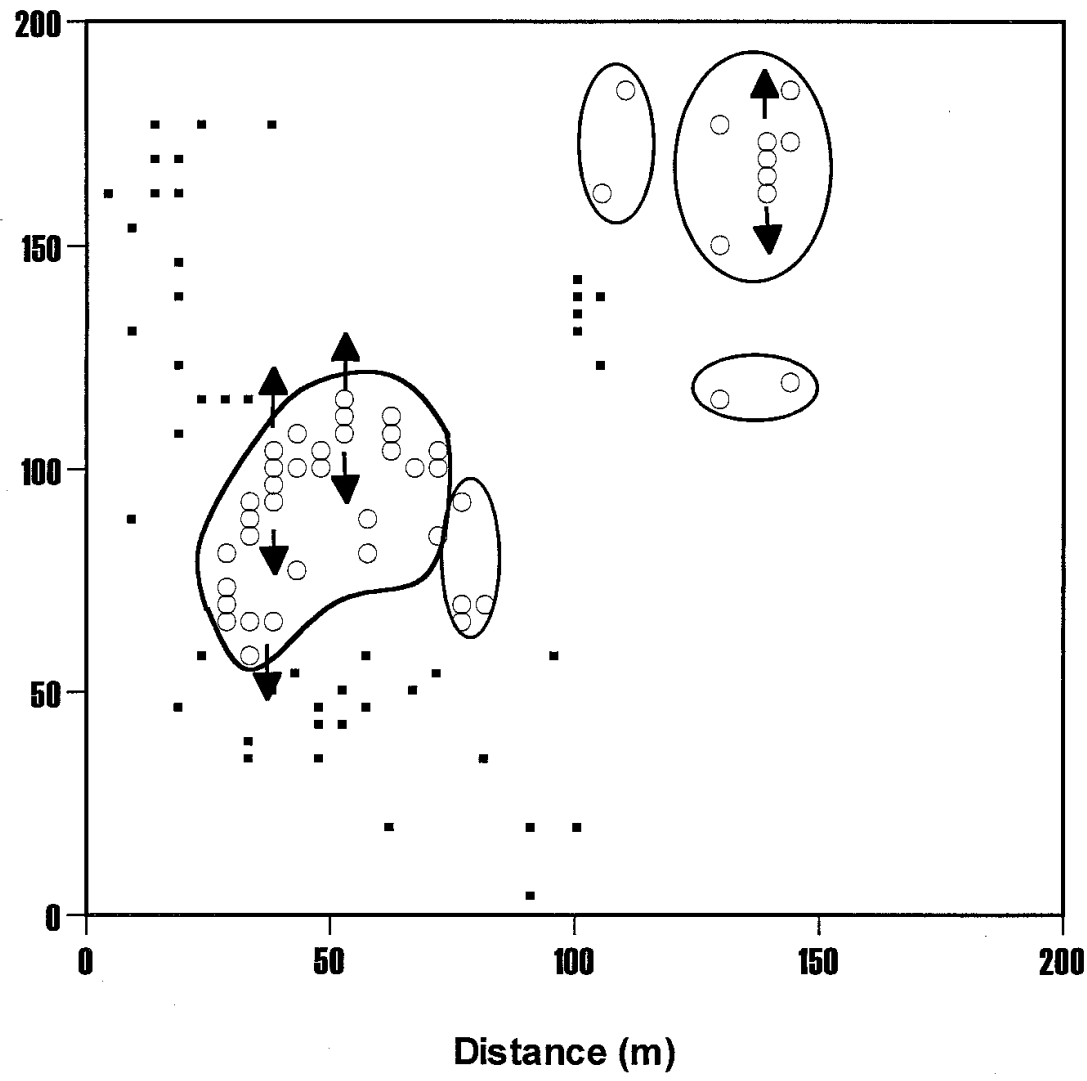

Fig. 3. Distribution of individual hosts, replanted trees, and five somatic incompatibility groups (SIGs) of Armillaria mellea at orchard 2. Open circles represent dead or dying pear trees from which A. mellea was isolated. Isolates from the same SIG are outlined. Arrows designate the direction of expansion of selected disease centers. Squares represent replants due to mortality by Armillaria root disease. Most of the remainder of the plot is occupied by symptomless trees in a $4 \times 8 \mathrm{~m}$ spacing.

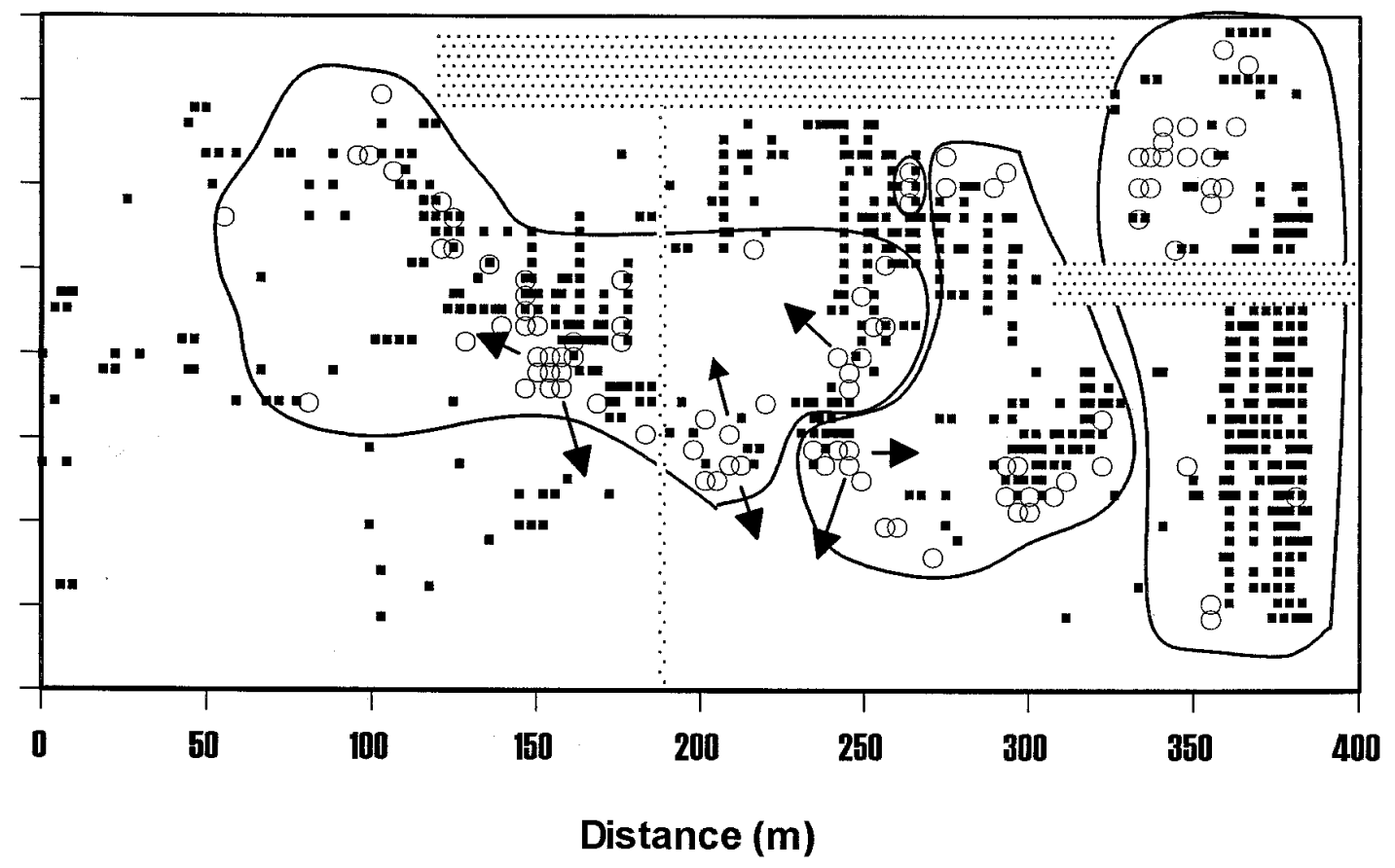

Fig. 2. Distribution of individual hosts, replanted trees, and four somatic incompatibility groups (SIGs) of Armillaria mellea at orchard 1. Open circles represent dead or dying pear trees from which A. mellea was isolated. Isolates from the same SIG are outlined. Arrows designate the direction of expansion of selected disease centers. Squares represent replants due to mortality by Armillaria root disease. Most of the remainder of the plot is occupied by symptomless trees in a $4 \times 4 \mathrm{~m}$ spacing. Patterned areas represent portions of orchard not planted to trees (see Fig. 1). 
center but included within the same SIG. The numerous replants seen in Figure 2 indicate that mortality due to Armillaria root disease has been heavy in this orchard for the past 15 years; approximately $10 \%$ of all trees in the area surveyed have been killed by the disease (Fig. 2).

Pairings among 54 diploid isolates identified five SIGs at orchard 2 (Fig. 3). The SIGs at orchard 2 were generally smaller than those detected at orchard 1 and ranged from 20 to $60 \mathrm{~m}$ in length. As was found at orchard 1, no intermingling was observed among the five different SIGs in orchard 2 (Fig. 3). Pairings between isolates from the two orchards were all negative and did not indicate any common SIGs.

Tree mortality in orchard 2 was more recent than in orchard 1 , and there were many fewer replants associated with the disease. Although not associated with any specific SIGs, replants along the west edge and toward the center of the plot were most likely the result of Armillaria root disease (Fig. 3). Decomposing fruiting bodies of Armillaria were observed on mature trees adjacent to these replants in March 1997. We were unable, however, to isolate from these mushrooms; in addition, the trees did not show extensive crown symptoms, and we were unable to locate mycelial fans in the root crown area.

Disease centers were more limited at orchard 2 than at orchard 1. For the two smallest SIGs, A. mellea was isolated from single trees $20 \mathrm{~m}$ apart separated by asymptomatic trees (Fig. 3). The largest SIG at orchard 2 consisted of 31 dead and dying trees in an area approximately $60 \mathrm{~m}$ long; mortality in this center has occurred mostly in the past 3 years. This large cluster of dead and dying trees actually consisted of a number of small disease foci that were expanding in several directions (Fig. 3, arrows).

Root excavations. Following extensive root excavations, Armillaria was observed on seven of nine trees at orchard 1 and five of 10 trees at orchard 2. At both sites, numerous independent infections by Armillaria were observed on the roots of diseased trees. Discrete lesions were scattered on root surfaces, ranging in size from several square centimeters to large lesions covering hundreds of square centimeters (Fig. 4A and C). In some cases, infections began far out on the root system; e.g., on one tree, a single decayed root $(4 \mathrm{~cm}$ diameter) was found approximately $3.25 \mathrm{~m}$ from the root crown area. In other instances, lesions were found primarily in the root crown area. On one tree, a $20 \times 30$ $\mathrm{cm}$ lesion was found at the root crown starting just below the soil surface, although no Armillaria was found on the large lateral roots (Fig. 4A). Armillaria apparently attacked most of the trees throughout their root system at many separate infection points. On three trees, lesions appeared to coalesce to almost
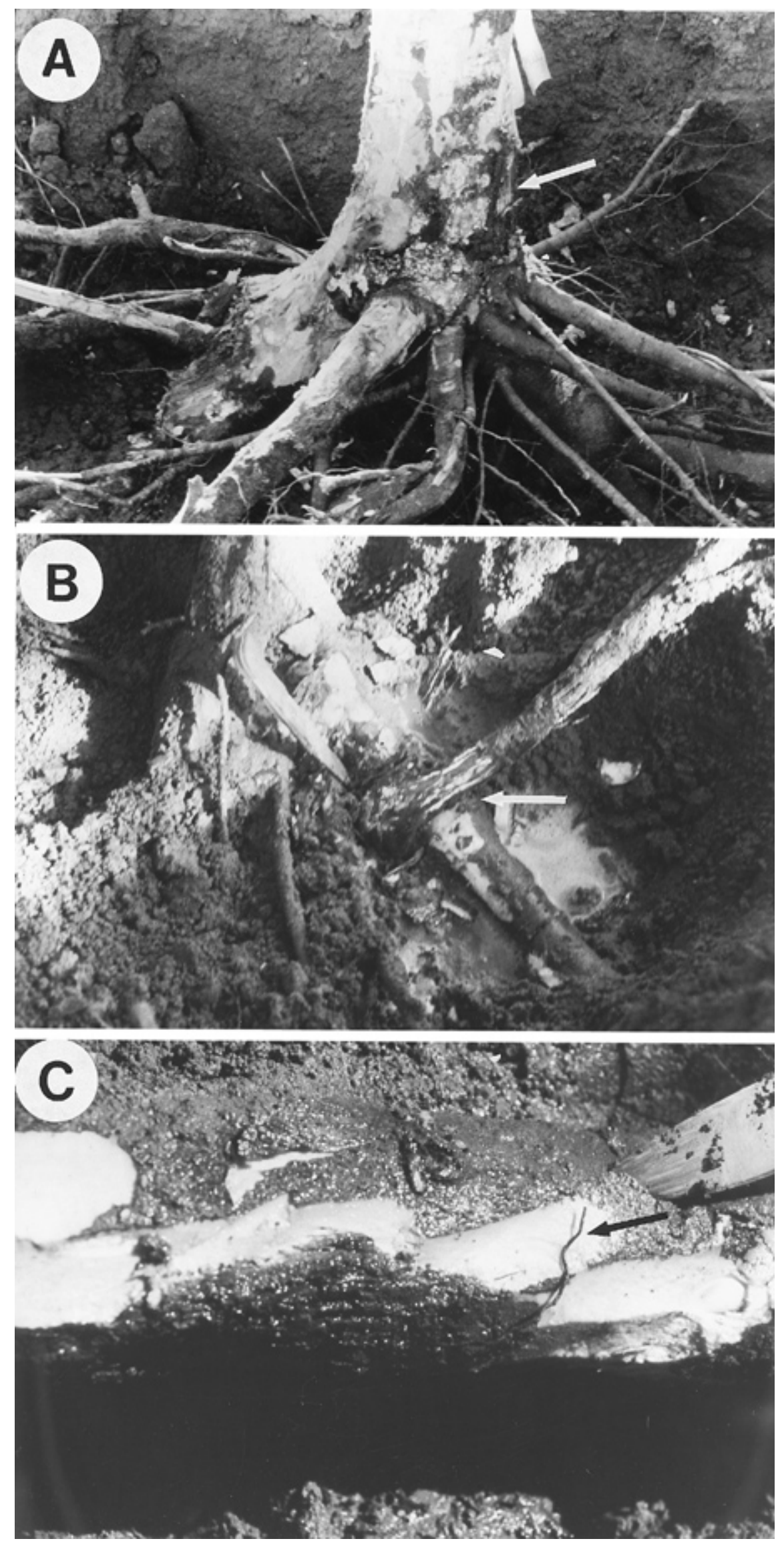

Fig. 4. Armillaria on pear root systems. (A) Excavated pear root system with large lesion at root collar caused by Armillaria (arrow). (B) Excavated pear root systems showing tree-to-tree transmission of Armillaria via root-to-root contact (arrow). (C) Rhizomorph (arrow) extending from lesion on large pear root. 
completely colonize the root system; however, we could still discern discrete lesions with uninfected tissue between the lesions.

The root system excavations revealed a lack of root contact or root grafts between adjacent pear trees. In general, roots from adjacent trees were separated by 30 to 60 $\mathrm{cm}$. Only one instance of transmission of Armillaria via root-to-root contact was observed in the 19 trees excavated (Fig. 4B). In fact, this was the only observed root-to-root contact between adjacent trees regardless of colonization by Armillaria.

Rhizomorphs were prevalent on root surfaces and in the soil at both sites. Rhizomorphs could be traced from small ( 3 to $5 \mathrm{~cm}$ diameter) lesions into the soil (Fig. 4C). Rhizomorphs could also be found on the walls of the excavation pit throughout the soil profile. Extension of rhizomorphs from diseased roots through the soil appeared to be limited to 30 to $60 \mathrm{~cm}$. This would be sufficient to bridge the gap between root systems of adjacent trees and between different roots on the same tree. Woody roots from the original stand of pear trees were also found in several of the root pits; most had Armillaria-type decay (i.e., white, spongy rot) and could have served as inoculum sources.

It was difficult to quantitatively assess the amount of Armillaria infection and assess the relative importance of various types of infection on individual trees. Trees that were near death always had extensive root collar colonization, in addition to much of the root system being colonized. One tree, however, had extensive root collar colonization (Fig. 4A) with very little Armillaria on the peripheral parts of the root system; this tree had some reduced growth (crown rating 2) but overall would not have been identified as an Armillariainfected tree based on crown condition. Trees with better crowns generally had Armillaria infections restricted to small lesions or to peripheral parts of the root system.

\section{DISCUSSION}

All isolates from dead and dying pear trees were identified by PCR analysis as $A$. mellea, although at least two other species of Armillaria (A. gallica Marxmuller \& Romagn. and A. nabsnona Volk \& Burdsall) have been found near pear growing regions in the coastal ranges and the Sierra Nevada foothills of California $(2,6)$. These latter two Armillaria species have only been associated with native vegetation and are relatively less virulent pathogens than A. mellea. To date, A. mellea sensu stricto is the only aggressive Armillaria species that has been identified from cultivated hosts (landscape and orchard) in California $(2,6)$.

We found that populations of Armillaria at both study sites consist of a few SIGs that are each found over large areas of the orchard. This supports the idea of longterm vegetative spread of the pathogen from a small number of initial infections and is consistent with other studies of the population biology of Armillaria $(3,8,10$, $19,20,22,25)$. In contrast, if recent basidiospore infection of hosts had been the primary means of spread of Armillaria in the pear orchards, we would have expected to detect numerous small SIGs.

Somatic incompatibility pairings are a simple method of delineating individual genotypes in field samples of Armillaria $(3,8,10,19,20,22,25)$. It should be pointed out, however, that inclusion in a single somatic incompatibility group does not necessarily mean that all isolates arose from a common mating. The genetic basis of somatic incompatibility in Armillaria is not known, although some reports have suggested that multiple genes may be involved $(8,10)$. Morphological rejection responses between paired mycelia indicate only differences at the somatic incompatibility loci and may not distinguish between closely related genotypes, such as those initiated by sibling matings (19). Such sibling matings, however, appear to be a rare event in the population biology of Armillaria. Use of additional data, such as mating alleles, isozymes, and molecular markers (nuclear and mitochondrial), to confirm somatic incompatibility pairings has only rarely revealed situations of sibling related genets $(3,19,20,22)$. Therefore, we feel that the use of somatic incompatibility alone is justified for identifying fungal individuals of Armillaria.

Pear trees have been grown on both of the study sites for approximately 100 years, yet significant mortality due to $A r$ millaria has apparently been confined to the last 10 to 20 years. In interpreting the data, we must first distinguish between the distribution and expansion of the SIGs and the distribution of individual disease centers. If we consider expansion of the SIGs (as outlined in Figs. 2 and 3) to be restricted to the past 10 to 20 years at both orchards, this would suggest linear growth of Armillaria up to $10 \mathrm{~m}$ per year for some of the larger SIGs (Figs. 2 and 3). This high rate seems unlikely, particularly in light of the observation that most spread by the fungus is by rhizomorph growth through soil. Our experiments with rhizomorph growth through orchard soils indicates rhizomorph extension of up to 10 $\mathrm{cm} /$ year (E. C. Whiting and D. M. Rizzo, unpublished). Spread rates of Armillaria in other studies $(7,8)$ have generally been estimated at 0.3 to $1.6 \mathrm{~m} /$ year. If similar rates of spread exist in our orchards, this would suggest the probability of somatic growth for the largest SIGs from an initial infection for up to 300 years, much longer than the 10 to 20 years during which tree mortality has been observed.

In California, A. mellea is native to hillside and riparian habitats in which oaks and other woody species grow $(2,6)$. Our preliminary studies in oak forests of the coastal ranges of California have found $A$. mellea to commonly occur on a large percentage of the trees. The fungus is found as epiphytic rhizomorphs or in small lesions scattered on the root systems of native vegetation. The size of individual SIGs in native woodlands appears to be quite large and is not associated with the formation of discrete disease centers (K. Baumgartner and D. M. Rizzo, unpublished). In fact, little mortality is associated with the fungus in native oak stands.

The observed distribution of disease centers within the two pear orchards most likely resulted from multiple infections via primary inoculum from previous woodlands rather than from extensive secondary spread of the SIGs between pear trees. Under this scenario, the SIGs were at or near their present size at the time the orchards were established. As trees were removed to establish orchards, residual woody tissues in the soil served as sources of primary inoculum to infect planted hosts. Secondary spread via rhizomorphs and, to a lesser extent, root-to-root contact is very important in the expansion of individual disease centers. Recent mortality of pear trees was noted both at the periphery of the SIGs and in what would be considered the center of the SIG. The most likely explanation for this distribution is that the fungus is found throughout the orchard and we are just seeing differences in how quickly the primary inoculum moves into the pear trees in different parts of the orchard.

While the size of many of the SIGs in the pear orchards suggests establishment prior to planting of the pear orchards, it is possible that some of the expansion of the SIGs to their present size occurred during the time since the pear orchards were planted. In this case, Armillaria would have spread throughout the pear orchards (via epiphytic rhizomorphs and root-to-root contact) on many of the trees without causing significant crown symptoms or mortality. This would be similar to what has been described for the spread of $A r$ millaria in native forests $(9,19,20)$ and similar to our findings for oak forests in California (as described above). Considering the lack of tree mortality due to Armillaria root disease during the first 80 years since the orchards were established, we cannot completely dismiss this hypothesis. However, the lack of Armillariacaused lesions on root systems of some trees at the periphery of disease centers supports the idea of patchy distribution of primary inoculum rather than extensive secondary spread of Armillaria through the orchard.

The above results indicate that the recent observations of mortality in pear orchards are not due to changes in the pathogen population. Our observations have also 
shown that pear trees of all ages and rootstocks are attacked by Armillaria. We believe, therefore, that changes in cultural practices may have had a major impact on the expression of Armillaria root disease in pears in California. High density plantings, increased yield and fruit size expectations, and intermittent periods of high rainfall and prolonged drought during the 1970s and 1980s may have led to enhanced tree stress. We are also examining the effects of under-tree sprinkler irrigation systems, which replaced flood irrigation during the 1970s, thereby facilitating more frequent, shallow irrigations. Sprinkler irrigation has resulted in continuously moist soil conditions, which favor Armillaria survival and growth, especially rhizomorph production. Rhizomorphs have not been considered an important part of the epidemiology of $\mathrm{Ar}$ millaria in California orchards $(1,16,17)$, most likely due to the dry conditions encountered in most growing areas in the state. However, increased irrigation may have led to conditions that are much more conducive to rhizomorph formation and spread. Increased moisture has been suggested to change the susceptibility to $\mathrm{Ar}$ millaria of native oak trees in landscape situations in California (16), and better water management may be effective in controlling the disease in pear orchards.

\section{ACKNOWLEDGMENTS}

The cooperation of Broc Zoller and Nick Ivicevich in setting up the field plots is greatly appreciated. PCR-based identifications of Armillaria were conducted by Kendra Baumgartner. Rob Gross of DendroTech (Calistoga, CA) provided the root excavations. The authors also thank Tom Harrington, Alan Biggs, and Doug Gubler for thoughtful comments on the manuscript. This study was supported by funding from the California Pear Advisory Board, University of California Division of Agriculture and
Natural Resources, and by a cooperative agreement with USDA-ARS.

\section{LITERATURE CITED}

1. Anonymous. 1991. Integrated pest management for apples and pears. University of California, Statewide Integrated Pest Management Project, Division of Agriculture and Natural Resources, Oakland, California. Publ. 3340.

2. Baumgartner, K., Raabe, R. D., and Rizzo, D. M. 1997. Identification and distribution of Armillaria species in California. Phytopathology 87:S7.

3. Guillaumin, J. J., Anderson, J. B., Legrand, P., Ghahari, S., and Berthelay, S. 1996. A comparison of different methods for the identification of genets of Armillaria spp. New Phytol. 133:333-343.

4. Harrington, T. C., and Wingfield, B. 1995. A PCR-based identification method for species of Armillaria. Mycologia 87:280-288.

5. Harrington, T. C., Worrall, J. J., and Baker, F. A. 1992. Armillaria. Pages 81-85 in: Methods for research on soilborne phytopathogenic fungi. L. L. Singleton, J. D. Mihail, and C. Rush, eds. American Phytopathological Society, St. Paul, MN.

6. Jacobs, K. A., MacDonald, J. D., Cobb, F. W., Jr., and Wells, K. 1994. Identification of Armillaria species in California. Mycologia 86:113-116.

7. Kable, P. F. 1974. Spread of Armillariella sp. in a peach orchard. Trans. Br. Mycol. Soc. 62:89-98.

8. Kile, G. A. 1983. Identification of genotypes and the clonal development of Armillaria luteobubalina Watling \& Kile in eucalypt forests. Aust. J. Bot. 31:657-671.

9. Kile, G. A., McDonald, G. I., and Byler, J. W. 1991. Ecology and disease in natural forests. Pages 102-121 in: Armillaria Root Disease. C. G. Shaw, III, and G. A. Kile, eds. U.S. Dep. Agric. For. Serv. Agric. Handb. 691.

10. Korhonen, K. 1978. Interfertility and clonal size in the Armillariella mellea complex. Karstenia 18:31-42.

11. Munnecke, D. E., Kolbezen, M. J., and Wilbur, W. D. 1973. Effects of methyl bromide or carbon bisulfide on Armillaria and Trichoderma growing on agar medium and relation to survival of A. mellea in soil following fu- migation. Phytopathology 63:1352-1357.

12. Munnecke, D. E., Kolbezen, M. J., Wilbur, W. D., and Ohr, H. D. 1981. Interactions involved in controlling Armillaria mellea. Plant Dis. 65:384-389.

13. Munnecke, D. E., Wilbur, W., and Darley, E. F. 1976. Effect of heating or drying on $\mathrm{Ar}$ millaria mellea or Trichoderma viride and the relation to survival of A. mellea in soil. Phytopathology 66:1363-1368.

14. Ogawa, J. M., and English, H. 1991. Diseases of temperate zone tree fruit and nut crops. University of California, Division of Agriculture and Natural Resources, Oakland, California. Publ. 3345

15. Ohr, H. D., Munnecke, D. E., and Bricker, J. L. 1973. The interaction of Armillaria mellea and Trichoderma spp. as modified by methyl bromide. Phytopathology 63:965-973.

16. Raabe, R. D. 1966. Testing plants for resistance to oak root fungus. Calif. Agric. 20:12.

17. Raabe, R. D. 1972. Variation in pathogenicity and virulence in single-spore isolates of $\mathrm{Ar}$ millaria mellea. Mycologia 64:1154-1159.

18. Raabe, R. D. 1979. Resistance or susceptibility of certain plants to Armillaria root rot University of California Publ. 2591.

19. Rizzo, D. M., Blanchette, R. A., and May, G. 1995. Distribution of Armillaria ostoyae genets in a Pinus resinosa - Pinus banksiana forest. Can. J. Bot. 73:776-787.

20. Rizzo, D. M., and Harrington, T. C. 1993. Delineation and biology of clones of Armillaria ostoyae, A. gemina, and A. calvescens. Mycologia 85:164-174.

21. Shaw, C. G., III, and Roth, L. F. 1976. Persistence and distribution of a clone of Armillaria mellea in a ponderosa pine forest. Phytopathology 66:1210-1213.

22. Smith, M. L., Bruhn, J. N., and Anderson, J. B. 1994. Relatedness and spatial distribution of Armillaria genets infecting red pine seedlings. Phytopathology 84:822-829.

23. Smith, R. E. 1941. Diseases of Fruits and Nuts. Calif. Agric. Ext. Serv. Circ. 120.

24. Thomas, H. E. 1934. Studies on Armillaria mellea (Vahl) Quel., infection parasitism and host resistance. J. Agric. Res. 48:187-218.

25. Worrall, J. J. 1994. Population structure of Armillaria species in several forest types. Mycologia 86:401-407. 